\title{
Globalization and Sustainability of Regions: The Role of Cultural and Creative Industries in Cutural Policies and their Implications for Regional Development - A Case Study of the Czech Republic
}

\author{
Blanka Wurst ${ }^{1, *}$ \\ ${ }^{1}$ Department of Humanities, Faculty of Economics and Management, Czech University of Life \\ Sciences Prague, Czech Republic
}

\begin{abstract}
This article examined the level of integration of the concept of Cultural and Creative Industries in strategic documents decisive for public policy implementation. On the case study of the Czech Republic, concrete goals, tools and measures of respective policies were examined, special focus has been laid on the implementation power and coordination mechanisms. In the methodological framework of the Multi-level Governance Concept, methods of content and comparative analysis were used. As the analysis shows, on the central level is the concept of CCIs explicitly reflected and very well elaborated, with concrete goals and instruments to achieve the given goals, on the local level predominantly the „cultural part" is stressed, having the „creative aspects" hidden in other policy areas. Concerning the local level, there is a „two axes" flow. On one side, examined policy paper stresses the importance of culture for own citizens, especially for the community and identity feeling, promotion of a good name of the city (region, municipality) and last, not least, the identification of citizens with the place they live in. On the other hand, the second line aims at attracting tourists through a complex combination of cultural heritage visits, connected with various experience events.
\end{abstract}

\section{Introduction}

In context of globalisation, todays Europe faces many new challenges. The Internet and digitalization are fundamentally changing the way people, businesses and governments interact. This has led to a new phase of globalization underpinned by the movement of data across national borders, changing the nature, patterns and actors in international trade in

\footnotetext{
* Corresponding author: hasovab@pef.czu.cz
} 
goods and services. [1] For Europe and other parts of the world, the rapid roll-out of new technologies and increased globalisation has meant a striking shift away from traditional manufacturing towards services and innovation. Factory floors are progressively being replaced by creative communities whose raw material is their ability to imagine, create and innovate. [2]

In this context, Florida \& al. (2008) poses the question: What really drives economic development? [3] According to current thinking and research in economics, geography and social science broadly, the underlying driver of economic development is highly skilled and educated people-what some call talent and what economists and social scientists frequently refer to as human capital. [3] On the other hand, in the European geographical scope, especially in the Central European space, the discussion focuses on the impact of EU funds on regional development. Horridge \& Rokicki (2018) argue that all regions of the Visegrad countries would have grown more slowly if those countries had not joined the EU. [4] In a more global context, Crescenzi \& Iammarino (2017) observe that corporate networks have dramatically altered regional connectivity and interdependence around the world. MNE networks have spurred spikier geographies and uneven regional development, depending on the variation across urban and regional innovative and institutional capabilities to cash in on the presence of global 'gatekeepers' to build new absolute and comparative advantages. [5]

Talent and effective use of skills are directly bound to creativity and innovation. According to Crescenzi \& Iammarino (2017), regional connectivity is the degree of twoway (inward and outward) openness that shapes the regional churn of skills, talent, competences and business functions/value chain stages.[5] Even when inflows and outflows are balanced, suggesting that an 'equilibrium' has been reached by the regional economy, the dynamic recombination of key cognitive and productive local assets leads to the enduring capability of cities and regions to adapt, react and develop in an ever-changing global environment. [5]

Migration/immigration plays also significant role. Especially in context of regional development, many rural communities in most European nations have been touched by counterurbanization for at least a period in the last forty years [6]. According to Woods (2016) in these communities in-migration has had a transformative impact. Not only has migration contributed to economic regeneration - both through the entrepreneurship of inmigrants and through the expansion of local markets - but it has also, more contentiously, inflated property prices and displaced local working class households in processes of gentrification, stoked environmental pressures with demands for more housing and infrastructure, diluted and marginalized local cultural traditions, and prompted local conflicts and power struggles. [6] Comparing to the situation in the US, refugees are incentivized and encouraged to participate in the reproduction of a 'symbolic economy' which valorizes images of cosmopolitanism, diversity and immigrant contribution for urban rebranding efforts. Through participation in this symbolic economy, refugees gain access to resources, recognition and decision makers. [7]

Culture, which according to the European Commission lies at the heart of human development and civilisation [8], can help overcome major societal challenges bring resources for local development. While creating jobs at local level - being performed by SMEs predominantly [9], fostering citizens participation in local communities, motivation and cooperation, while tackling questions of social inclusion and immigration on a local decision-making level, this concept goes far beyond regular economic indicators.

In recent years, policy makers reflect this fact in documents and strategies, essential for public policy decisions. Starting with international organizations, e. g. UNESCO, 
UNCTAD, OECD or WIPO, following the decision-making institutions of the European Union, the European Commission in particular, central governments produce national strategies and concepts. On a regional level, also a growing attention is being paid to an effective use of available cultural and creative sources in order to increase economic growth. This is evident especially on the example of big cities. Still, how is the situation on local level? What is the perception of the Cultural and Creative Industries concept in strategic documents of small to middle sized municipalities? Is there any complex and systematic approach in policy making and policy implementation?

\section{Methods}

The purpose of this article is to examine the level of integration of the concept of Cultural and Creative Industries in strategic documents decisive for public policy implementation. The analysis focuses on a comparative study of CCI's concepts' perception in national and local policy papers. On the case study of the Czech Republic, concrete goals, tools and measures of respective policies are examined, special focus is laid on the implementation power and coordination mechanisms. Methods of description, content analysis and comparative analysis in the multi-level governance context are being used.

\section{Results}

\subsection{The Concept of Cultural and Creative Industries in a global perspective - international institutional framework}

The concept of CCIs reflects rapid changes connected with the phenomenon of globalisation. As CCI's are by nature inter-disciplinary, they combine culture on one hand, economy on the other and many other connected areas as education, innovation etc. (synergies can be illustrated on the scope to exploit geographical specificities as assets, notably in relation to cultural tourism and renewable energy in context of the ERDF impact on economic development in selected European regions[10].) They are becoming increasingly important components of modern post-industrial knowledge-based economies. [11] On a global institutional scale, one of the main promoters of this concept is the European Commission, which builds upon initial efforts of the UNESCO to conceptualize and methodologically approach this rapidly developing sector. Already in the year 1978, The General Conference of UNESCO approved the implementation of a comparative research programme on cultural industries. [12] In 1986, UNESCO published its landmark Framework for Cultural Statistics (FCS) which was the first comprehensive attempt to develop common methodologies to capture information about cultural activities. This framework was subsequently adopted by various national institutions which then adapted and modified the methodology to reflect the specific cultural realities of their country.[13] Compare e.g. with the way the World Bank collects the data for development statistics. [14]. The OECD does not stay behind with the definition. „The past decades have seen a rapid emergence of the culture and creative economy. Culture and Creative industries include a broad range of activities, including cultural heritage, architecture, music, live performance, publishing, the art and antiques market, music, arts and crafts professions, television and radio, film and video, advertising, design, fashion, video games, and 
software and IT services. [15] However, due to the rapid evolution of CCIs, the difficulties to define its frontiers and its needs, the often intangible impacts of culture-led projects, the need to catch up with the new trends in cultural and creative tourism, and the fragmentation of the policy frameworks, local policy makers often do not grasp the full extent of the sector, and deploy insufficient efforts to support it. There is overall a lack of capacities to design integrated strategies and in leveraging the appropriate policies that would be necessary to realise the potential of the sector in creating jobs and generating well-being. [15]

According to the European Commission, Cultural and Creative Industries are in a strategic position to promote smart, sustainable and inclusive growth in all EU regions and cities, and thus contribute fully to the Europe 2020 Strategy, which is the EU's growth strategy for the coming decade. [11, 16]. Another key document of the European Commission in context of the CCI's, The Green Paper on Unlocking the potential of cultural and creative industries, states that: "Cultural industries" are those industries producing and distributing goods or services which at the time they are developed are considered to have a specific attribute, use or purpose which embodies or conveys cultural expressions, irrespective of the commercial value they may have. Besides the traditional arts sectors (performing arts, visual arts, cultural heritage - including the public sector), they include film, DVD and video, television and radio, video games, new media, music, books and press. "Creative industries" are those industries which use culture as an input and have a cultural dimension, although their outputs are mainly functional. They include architecture and design, which integrate creative elements into wider processes, as well as subsectors such as graphic design, fashion design or advertising. [2] This definition of the concept is used also in this article for further analysis.

\subsection{Case study of the Czech Republic}

\subsubsection{Content analysis of the central government level - The National Cultural Policy of the Czech Republic for the years 2015 - 2020 (with an outlook to 2025)}

\subsubsection{Vision, goals and principles}

The National Cultural Policy of the Czech Republic for the years 2015 - 2020 goes back to the former strategy - NCP for the years 2009 - 2014. As the Ministry of Culture proclaims, ,the Government will focus on two new priorities: the development of cultural $\&$ creative sectors and the introduction of eCulture as an equivalent and consistent component of the eGovernment system. [17] „A new understanding of culture is necessary, taking into mind its correlation to the economy, the education system and a broader social background. Through the Ministry of Culture ("MoC") and in collaboration with other ministries and local governments, the state has the task to preserve the values of the cultural heritage and to integrate them in the present life of the society. By legislative means, economic instruments and tax policies, it should create a social climate conducive to the development of arts and to the stimulation of creativity to develop cultural \& creative sectors. The safeguarding of established cultural values, the creation of new ones and their use for educational purposes, as well as in an economy based on cultural \& creative industries guarantee both their transmission to future generations and their further dissemination." [17]. 


\subsubsection{Regional and local level as reflected in the National Cultural Policy}

„Creating conditions for the decentralisation of decision-making in the cultural system as a whole and for the transference of decision-making processes outside the authority of the state administration“, [17] seem to be also important. The Strategy states that „6 of 14 regions adopted policy documents aimed explicitly at the promotion of culture. Other regions address cultural priorities in general policy documents; culture is usually perceived as a field that is important for the development of tourism. Regional coordination mechanisms - regional commissions were created in order to use the cultural heritage more effectively. Activities in the area of cultural heritage are coordinated between the state, regions, municipalities and other subjects as well as between regions themselves. This shall lead to a more systematic and sustainable approach and use of the cultural heritage potential.[17]

\subsubsection{Instruments and implementation}

Government's instruments for the enforcement of the proposed goals shall be, according to the document, legislative, economic, guidance, institutional, control, social and technological. [17] In the context of CCI's, this shall mean especially the „encouraging Cultural and Creative Sectors“, while „Proposing interdepartmental tools to promote competitiveness of the cultural \& creative sectors.“ [17] The strategy proclaims that „The Ministry of Culture will propose a Framework national program of promotion of cultural \& creative sectors and it will continue to encourage presentations at major trade fairs." [17] The objective of the Ministry is also to increase the involvement of the private sector in the presentation of Czech culture abroad and to link artistic and business activities. Finally, the continuing in the program of mapping and analysing the cultural \& creative sectors and their potential that has been started already in 2011, is intended. [17]

\subsubsection{Regional and local levels - the Mnišek pod Brdy Municipality}

Culture-based development has relevance for regions in all stages of development - in the 'convergence' regions, where support for infrastructural development may continue to be needed, but also in both convergence and 'competitiveness' regions where the infrastructure and other local resources can be exploited to enhance the comparative advantages of the local economy and to stimulate creativity and enterprise.[11] While analysing the local level, the municipality of Mníšek pod Brdy has been selected. It is a municipality in the Central Bohemian Region, $27 \mathrm{~km}$ from the Capital Prague. There are currently 5749 inhabitants living in the small city. The municipality has its Strategic Plan for the next middle-term-period (2019 - 2028). This Strategic Plan builds on the questionnaire carried out between citizens of the municipality and on a consequently elaborated SWOT analysis created by experts of working groups of the municipality. [18] This significantly democratic element in the process, a system of consultations between the municipality authorities and citizens (questionnaires, regular consultations between citizens and the mayor of the city), confirms the findings of Lalicic \& Önder (2018) that residents are known to help decision-makers in making better decisions, solutions and design services as a result of their own experiences and knowledge [19]. Various studies show that if cities listened to residents' voices in the early stages of planning, problems could be 
addressed in time and failures could be prevented. As a result, there is a vast amount of research dedicated to involving residents in planning projects [19].

\section{Discussions}

According to the investigated policy documents, it is possible to say that on a central level, there is a big potential for the cooperation between ministries responsible for certain parts of the Cultural and Creative Industries. Even though there are many possibilities to finance CCI's through many operational programmes, more complex and profound synergies shall be set up between relevant ministries responsible for the overwhelming CCI's problematics. Further, questions of measurement could ease the situation. As today, various sectors are being considered separately, not in the overwhelming complexity, lot of data gets lost. Finally, as the Green Paper on Unlocking the potential of cultural and creative industries states, ,for CCIs to be able to make the most of the opportunities offered by cultural diversity, globalization and digitization, which are the key drivers for the further development of these industries, the challenge is: a) to put the right enablers in place by increasing the capacity to experiment, innovate and succeed as entrepreneurs, and providing easier access to funding and the right mix of skills; b) to help CCIs develop in their local and regional environment as a launch pad for a stronger global presence, including through increased exchange and mobility; and c) to move towards a creative economy by catalysing the spill-over effects of CCIs on a wide range of economic and social contexts.[2]

\section{Conclusions}

The study has shown that the concept of CCIs is well elaborated and perceived in the main strategic documents of the central level, the National Cultural Policy of the Czech Republic $(2015$ - 2020). Concrete goals are given, instruments are set. On the local level, predominantly the „cultural part“ is stressed, having the ,creative aspects“ hidden in other policy areas (education, leisure activities). The examined policy paper stresses the importance of culture for own citizens, especially for the community and identity feeling, promotion of a good name of the city (region, municipality) and last, not least, the identification of citizens with the place they live in. On the other hand, the second line aims at attracting tourists through a complex combination of cultural heritage visits, connected with various experience events, be it festivals, fairs including creative aspects (local artists and creators), museums, gastronomy events, music, theatre, dance and other art performances.

\section{References}

1. S. Fayyaz, A Review on Measuring Digital Trade \& E-Commerce as New Economic Statistics Products. Statistics and Economy Journal 99, 57 - 68 (2019)

2. European Commission: Green Paper on Unlocking the potential of cultural and creative industries, COM (2010) 183 final (Brussels, 2010), available on-line at: https://eur-lex.europa.eu/legal-content/EN/ALL/?uri=celex\%3A52010DC0183, retrieved on 7.8. 2018 
3. R. Florida, Ch. Mellander, K. Stolarick, Inside the black box of regional development - human capital, the creative class and tolerance. Journal of Economic Geography 8, 615-649 (2008)

4. M. Horridge, B. Rokicki, The impact of European Union accession on regional income convergence within the Visegrad countries. Regional Studies 52, 503-515 (2018)

5. R. Crescenzi, S. Iammarino, Global investments and regional development trajectories: the missing links. Regional Studies 51, 97-115 (2017)

6. M. Woods, International Migration, Agency and Regional Development in Rural Europe. Documents d'Anàlisi Geogràfica 62, 569-593 (2016)

7. J. Watson, Welcoming refugees and the cultural wealth of cities: Intersections of Urban Development and Refugee Humanitarianism. International Journal of Urban and Regional Research 43, 983 - 999 (2019)

8. European Commission: Communication from the Commission to the European Parliament, the Council, the European Economic and Social Committee and the Committee of the Regions on a European agenda for culture in a globalizing world, COM (2007) 242 final (Brussels, 2007), Available online at: https://eurlex.europa.eu/LexUriServ/LexUriServ.do?uri=COM:2007:0242:FIN:EN:PDF, retrieved on 7.7.2018

9. A. R. Cruz, R. N. Almeida, P. Costa, M. A. Gato, M. Perestrelo, Knowledge Transfer in the Cultural and Creative Sector: Institutional Aspects and Perspectives from Actors in Selected Atlantic Regions. Social Sciences 8, (2019)

10. U. Fratesi, F. G. Wishlade, The impact of European Cohesion Policy in different contexts. Regional Studies 51, 817-821 (2017)

11. European Union OMC, Expert group on Cultural and Creative Industries: Policy Handbook on the Strategic Use of EU support programmes to foster the potential of culture for local, regional and national development and the spill-over effects on the wider economy, (Brussels, 2012) Available on-line at: http://ec.europa.eu/assets/eac/culture/library/reports/policy-handbook_en.pdf, retrieved on 14.10 .2019

12. UNESCO: Cultural industries: A challenge for the future of culture (Paris, 1982), Available on-line at: http://unesdoc.unesco.org/images/0004/000499/049972eo.pdf, retrieved on 27.3.2018

13. UNESCO Institute for Statistics: The 2009 UNESCO Framework for Cultural Statistics,

(Paris, 2009), Available on-line at: http://unesdoc.unesco.org/images/0019/001910/191061e.pdf, retrieved on 3.8.2018

14. B. M. Djayeola, T. Fujs, Policies, Technology, and Quality Returns from the World Development Indicators. Statistics and Economy Journal 98, 399 - 404 (2018)n̆

15. OECD: Fulfilling The Potential For Cultural And Creative Industries (CCIs). Mapping the sector and identifying policy tools to support it. (Trento) Available on-line at https://www.oecd.org/cfe/leed/Fulfilling-the-potential-for-CCI-projectdescription.pdf, retrieved on 14.7.2018

16. European Commission: EUROPE 2020 A strategy for smart, sustainable and inclusive growth. COM (2010) 2020 final (Brussels, 2010), available on-line at: https://eurlex.europa.eu/legal-content/EN/TXT/?uri=celex:52010DC2020, retrieved on 28.5.2019 
17. Ministry of Culture of the Czech Republic: National cultural policy 2015-2020 (2025), (Praha, 2016), available on-line at: https://www.mkcr.cz/cultural-policy-of-the-czechrepublic-983.html?lang=en, retrieved on 30.5.2019

18. Mníšek pod Brdy Municipality: Strategic Development Plan of the municipality of Mníšek pod Brdy for the years 2019 - 2028 (Strategický plán rozvoje města Mníšek pod Brdy na období 2019-2028) (Mníšek pod Brdy, 2019), available on-line at: https://www.mnisek.cz/e_download.php?file=data/editor/262cs_5.pdf\&original=SPR M\%20Mn\%C3\%AD\%C5\%A1ek\%20pod\%20Brdy\%20-

$\% 20 \mathrm{~N} \% \mathrm{C} 3 \% \mathrm{~A} 1$ vrhov\%C3\%A1\%20\%C4\%8D\%C3\%A1st\%20\%28final\%29.pdf, retrieved on 3.9.2019

19. L. Lalicic, I. Önder, Residents' Involvement in Urban Tourism Planning: Opportunities from a Smart City Perspective. Sustainability 10, (2018) 